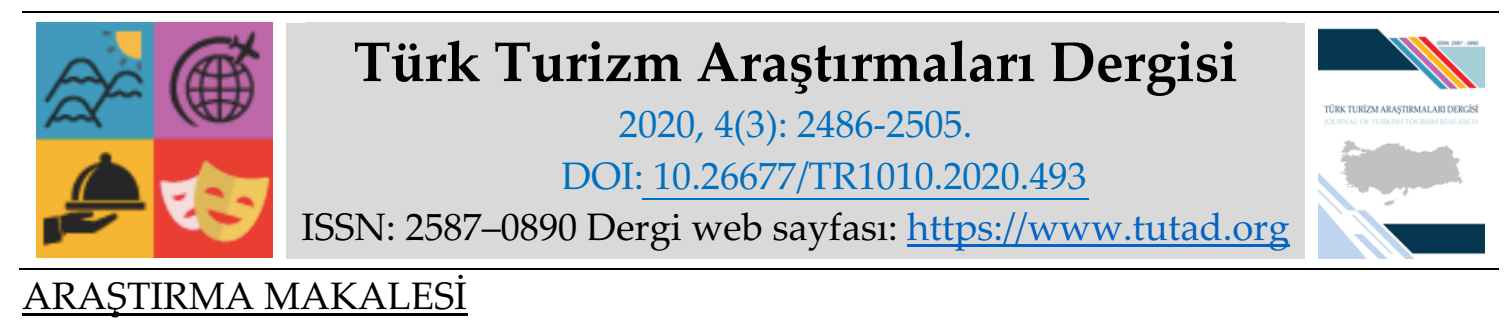

\title{
Turistik Bölgelerde Yaşayan Yerel Halkın Rekreatif Faaliyetlerine Yönelik Algılamaları: Kapadokya Bölgesi Örneği
}

Arş. Gör. Sevim KÜL AVAN, Nevşehir Hacı Bektaş Veli Üniversitesi, Turizm Fakültesi, Nevşehir, e-posta: sevim.kul@nevsehir.edu.tr ORCID: https://orcid.org/0000-0003-3103-381X

Prof. Dr. Suat KARAKÜÇÜK, Gazi Üniversitesi, Spor Bilimleri Fakültesi, Ankara, e-posta: ksuatt@gazi.edu.tr

ORCID: https://orcid.org/0000-0001-9144-7307

Öz

Turizm ve rekreatif faaliyetler destinasyona gelen ziyaretçileri etkilediği gibi yerel halkı da olumlu ve olumsuz şekilde etkilemektedir. Bundan dolayı turizm bölgelerindeki önemli bir paydaş olan yerel halkın rekreasyon faaliyetlerinin gelişimine karşı algıları araştırılmalı ve sonuçlar doğrultusunda gerekli planlamalar yapılmalıdır. Araştırmanın amacı, turizm bölgelerinde yaşayan yerel halkın, bölgede yapılan rekreatif faaliyetlerine yönelik tutumlarını belirlemek, rekreatif faaliyetlerin halk üzerinde etkilerini tespit etmektir. Araştırmada veri toplama yöntemi olarak yüz yüze görüşme tekniği kullanılmıştır. Çalışmanın verileri 2019 yılı Aralık ayı içerisinde Kapadokya Bölgesi'nde ikamet eden 22 kişiyle görüşme yapılarak elde edilmiştir. Çalışma sonucunda yerel halkın bölgede turizm faaliyetlerinin yapılmasından rahatsız olmadı ğı belirlenmiştir. Bunun yanında turistlerin bölgeye gelmesinin olumlu sonuçları içinde en çok gelir ve istihdam üzerinde etkisinin olduğu, olumsuz sonuç olarak ise fiyat pahalılığı yaratması olduğu belirlenmiştir.

Anahtar Kelimeler: Rekreatif Faaliyet, Turizm, Yerel Halk, Kapadokya.

Makale Gönderme Tarihi: 15.04 .2020

Makale Kabul Tarihi: 02.07.2020

\section{Önerilen Atıf:}

Kül Avan, S. ve Karaküçük, S. (2020). Turistik Bölgelerde Yaşayan Yerel Halkın Rekreatif Faaliyetlerine Yönelik Algılamaları: Kapadokya Bölgesi Örneği, Türk Turizm Araştırmaları Dergisi, 4(3): 2486-2505.

(C) 2020 Türk Turizm Araştırmaları Dergisi. 


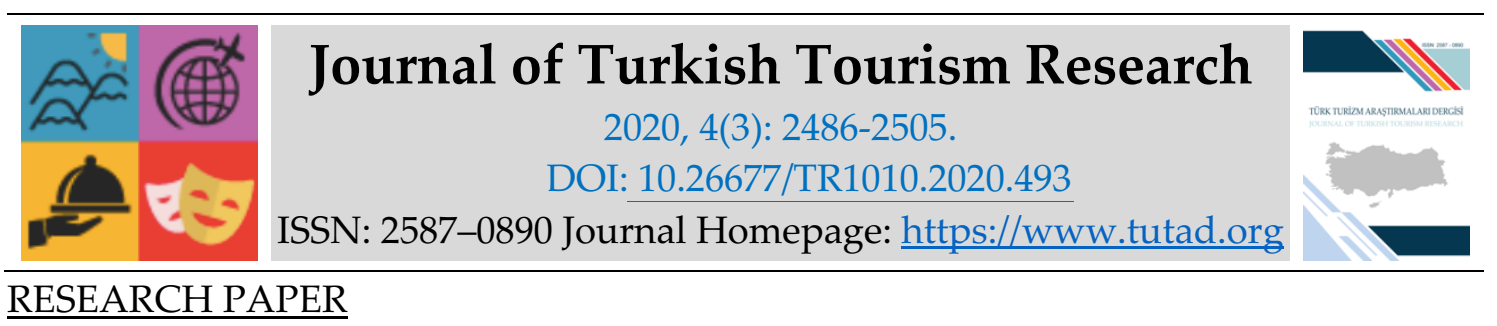

\title{
Perceptions of Local People Living in Touristic Regions for Recreative Activities: Example of Cappadocia Region
}

Research Assistant Sevim KÜL AVAN, Nevşehir Hacı Bektaş Veli University, Faculty of Tourism, Nevşehir, e-mail: sevim.kul@nevsehir.edu.tr ORCID: https://orcid.org/0000-0003-3103-381X

Prof. Dr. Suat KARAKÜÇÜK, Gazi University, Sports Science Faculty, Ankara, e-mail: ksuatt@gazi.edu.tr

ORCID: https://orcid.org/0000-0001-9144-7307

\begin{abstract}
Tourism and recreational activities affect the visitors to the destination as well as the local people positively and negatively. Therefore, the perceptions of local people, who are an important stakeholder in the tourism regions, towards the development of recreation activities should be investigated and necessary planning should be made in line with the results. The aim of the research is to determine the attitudes of local people living in tourism regions towards recreational activities in the region and to determine the effects of recreational activities on the public. In the research, face to face interview technique was used as data collection method. The data of the study were obtained by interviewing 22 people residing in Cappadocia Region in December 2019. As a result of the study, it has been determined that the local people are not disturbed by the tourism activities in the region. In addition, it has been determined that the most positive results of the tourists coming to the region have the most impact on income and employment, and the negative result is that it creates price expensive.
\end{abstract}

Keywords: Recreative Activity, Tourism, Local People, Cappadocia.

Received: 15.04 .2020

Accepted: 02.07.2020

\section{Suggested Citation:}

Kül Avan, S. and Karaküçük, S. (2020). Perceptions of Local People Living in Touristic Regions for Recreative Activities: Example of Cappadocia Region, Journal of Turkish Tourism Research, 4(3): 2486-2505.

(C) 2020 Türk Turizm Araştırmaları Dergisi. 


\section{Gíriş}

Turizm dünyanın en hızlı büyüyen sektörlerinden birisidir. Çünkü insanlar yoğun ve yorucu iş hayatının stresinden kaçma, dinlenme, eğlenme, değişik yerleri görme amacıyla bulunduğu yerden ayrılıp farklı yere seyahat ederek turizm olayı gerçekleştirmektedir. İnsanların ihtiyaçlarının ve beklentilerinin hızlı bir şekilde değiştiği günümüzde turizm sektörü içerisinde yer almak için rekabet etme çabası artmaktadır. Bu yüzden turizm endüstrisi çeşitlilik arz eden, farklı destinasyonlarda farklı turizm türlerini ve rekreatif faaliyetleri ortaya çıkarmaktadır. Bir destinasyonun cazibe öğeleri artırmak destinasyonun diğerlerinden farklılaşmasını ve rekabet gücünü artırmasını sağlamaktadır (Özdemir 2014: 44).

Turizm sektörü içerisinde turistleri seyahat etmeye iten farklı motivasyon unsurları bulunmaktadır. Bu motivasyon kaynakları arasında dinlenme, fiziken ve ruhen kendini yenileme isteği, yaşadığı yerden kısa süreliğine ayrılma, kültürel ve tarihi yerleri görme, doğayla yakınlaşma, farklı insanlarla tanışma, eğlenme, macera yaşama ve spor yapma gibi unsurlar yer almaktadır (İçöz ve Kozak 2002: 89; Birinci ve Güçer, 2019)). Günümüzde rekreasyon faaliyetleri turizmi geliştirmek için kullanılan önemli bir pazarlama stratejisi arasında bulunmaktadır. Çünkü rekreatif faaliyetler destinasyona farklılık katmakta, destinasyona olan talebi artırmakta, destinasyonun imajına olumlu katkı sağlamakta, turizmin yaratmış olduğu mevsimsellik sorununu ortadan kaldırma açısından fayda sağlamaktadır. Bu yönüyle rekreatif faaliyetler turizm endüstrisi içerisinde önemli bir turistik çekicilik unsuru olarak görülmektedir. Destinasyon içerisinde sunulan faaliyetlerin bölgenin taşıma kapasitesine uygun olarak gerçekleştirilmesi destinasyonun varlı̆̆ını sürdürmesi, yıpratılmaması ve sürdürülebilirliği açısından önemli görülmektedir (Karaküçük ve Akgül, 2016:195).

Son zamanlarda yerli halkın turizme ve turizmin etkilerine ilişkin tutumlarını incelemek oldukça ilgi duyulan araştırma konusu olarak göze çarpmaktadır. Fakat turistik bölgelerde yapılan rekreatif faaliyetlerin bölge halkı için anlamı ve algısı literatürde çok yer almamıştır. Bir bölgede yapılan turizm faaliyetlerinden en çok etkilenenler bölgede yaşayan insanlardır. O yüzden araştırmalarda bölge halkının eğilimini incelemek önemli bir gerekçe olarak görülmektedir. (Yılmaz, 2017). Destinasyonda yaşayan halkın turizm ve rekreatif faaliyetlere ilişkin algı, tutum ve görüşlerinin tespit edilmesi destinasyonu geliştirme politikalarının oluşturulması ve sürdürülebilirliğinin sağlanması açısından önemli bulunmaktadır (Yoon vd., 2001).

Çalışma alanı olarak seçilen Nevşehir ili doğal, tarihi ve kültürel dokusuyla Türkiye'nin en önemli turizm merkezlerinden biridir. Kiliseler, yer altı şehirleri, açık hava müzeleri, peri bacaları ve kaya otelleri ile en büyük mağara yerleşiminin bulunduğu Kapadokya'nın merkezi sayılan Nevşehir her yıl hem yerli hem de yabancı çok sayıda turisti ağırlamaktadır. Dünya Miras Listesi'nde yer alan bölge doğal güzelliği, zengin tarihi ve kültürel mirasının yanında çeşitli rekreatif faaliyetlerin de bulunduğu önemli bir çekicilik unsuru konumundadır. Bu çalışmada, yerel halkın rekreatif faaliyetlere ilişkin algılamaları araştırılmıştır. Çalışmada turizm bölgelerinde yaşayan yerel halkın turizme ilişkin tutumları ve rekreatif faaliyetlerin ekonomik, çevresel, sosyo-kültürel etkilerinin belirlenmesi amaçlanmaktadır. Yapılan bu çalışmanın önemli turizm destinasyonlarında yaşayan toplumun rekreatif etkinlik dinamiklerini daha iyi anlamak için önemli katkılar sağlayacağı düşünülmektedir.

\section{TURIZM ve REKREASYON FAALIYYETLERININ YEREL HALK ÜZERINDE ETKILERI}

Yerel halk turizm ve rekreatif faaliyetler için en önemli paydaşlardan biridir. Bu yüzden yerel halkın turizm ve rekreatif faaliyetlere karşı algılarını belirlemek yapılacak planlamalar açısından 
önemlidir. Turizm faaliyetlerinin yerel halk tarafından desteklenip desteklenmediğini tespit etmek amacıyla çalışmaların yapılmasının önemli ve gerekli olduğu düşünülmektedir (Nunkoo vd., 2013). Çünkü yerli halkın turizme karşı tutumlarının göz ardı edilmesi destinasyondaki turizmin gelişmesini ve planlanan başarıyı yakalama üzerine kötü sonuçlar verebilmektedir (Biçici, 2014). Yurtdışında turizm destinasyonunda bu konuda pek çok çalışmalar yapılmıştır. Yerel halkın turizme karşı algısı hakkında son yıllarda ülkemizde de birçok çalışma yapıldığı görülmüştür. Sivas'ta yaşayan yerel halk üzerine gerçekleştirilen çalışma sonucu Alaeddinoğlu (2008) genel olarak şehirde turizmin gelişimine olumlu bakıldığını belirlemiştir. Gümüş ve Özüpekçe (2009)'nin çalışması sonucu Foça halkının turizme yönelik algılarının olumlu olduğu tespit edilmiştir. Afyonkarahisar'da yapılan başka bir çalışma (Özdemir ve Kervankıran, 2011) sonucunda da yöre halkının bölgede turizmin gelişimi hakkında olumlu düşündüğü belirtilmiştir. Mesci ve Dönmez (2016)'nin Mudurnu'da yaşayan halkın turizmin faaliyetlerini destekledikleri sonucuna varılmıştır. Mardin'de yapılan çalışma da (Toprak, 2015) bölge halkının turizmin gelişmesi ile birlikte olumlu değişimler olabileceği belirtilmiştir. Uslu ve Kiper (2006)'in Beypazarı halkı üzerinde yaptığı çalışma yerel halkın \%97'sinin turizmin olumlu etkilerini hissettikleri belirlenmiştir. Van halkı üzerinde yapılan çalışma (Alaeddinoğlu, 2007) sonucu bölge halkının turizme ve gelen turistlere karşı bölge halkının olumlu tutum gösterdiği belirlenmiştir. Akova (2006) 'ın Cumalıkızık' da 2001 ile 2003 yılları arasında yerel halkın turizme ilişkin tutumları arasında fark olup olmadığına ilişkin yaptığı çalışmasında halkın turizme ilişkin tutumlarının 2001 yılında 2003 yılına göre halkın turizme yönelik halkın tutum seviyesinin olumlu şekilde arttığı belirlenmiştir. Oğuzbalaban (2017)'ın Türkiye'deki turizm bölgelerinde yaşayan yerel halkın turizmin etkilerine ilişkin algılarını belirlemeye yönelik yapılan çalışma sonrası genel olarak yerel halkın turizmin etkilerine ilişkin algılarının ve turizme bakış açılarının çoğunlukla olumlu yönde olduğu belirlenmiştir.

Turizmin yerel halkın üzerinde etkilerine yönelik birçok çalışma yapıldığı görülmüştür. Yapılan çalışmalarda yerel halk için olumlu ve olumsuz sonuçları olduğu belirlenmiştir. Turizmin yöre halkı üzerinde etkisini inceleyen çalışmalarda genellikle üç faktör üzerinde yoğunlaşılmıştır. Bunlar, ekonomik etkiler, sosyo-kültürel etkiler ve çevresel etkilerdir (Avcıkurt, 2015: 47 ).

\section{Turizm ve Rekreasyon Faaliyetlerinin Yerel Halk Üzerinde Ekonomik Etkileri}

Turizm ve rekreastif faaliyetlerinin turizm destinasyonu ve yerel halk için ekonomik anlamda birçok etkisi bulunmaktadır. Turizm ve rekreasyon faaliyetleri ülke ekonomisini artırmak için önemli bir gelir kaynağı oluşturmaktadır (Eshliki ve Kaboudi, 2012: 334; Yayla ve Yaylı,2019). Bunun yanında Karagöz (2006: 6) rekreatif faaliyetlerin turizmi çeşitlendirmekte olduğunu ve halk için yeni gelir kaynakları oluşturabileceğini belirtmiştir.

Yapılan çalışmalar sonucu olumlu ekonomik etki olarak halk tarafından bölge ekonomisinin geliştiği ve yeni turistik alanların inşaa edilmesini sağladığı (Bayat, 2010), halka yaptığı çalışmada ek gelir imkanı sağladığı (Eren ve Aypek, 2012; Gülüm ve Boz, 2014), istihdam sağlamaya ve bölgenin gelişmesine yardımcı olduğu (Yoon vd.,2001; Çımat ve Bahar, 2003; Vatan ve Zengin, 2015; Sandal ve Karademir,2016; Hançer ve Mancı,2017) belirtilmiştir. Yapılan çalışmalar sonucu turizm ve rekreatif faaliyetlerin ekonomik anlamda olumlu etkileri olduğu gibi halk üzerinde olumsuz etkilerinin de olduğu görülmüştür. Halk olumsuz ekonomik sonuç olarak halkın turizmin etkisiyle bölgedeki pek çok mal ve hizmetlerin fiyatlarının yükseleceğini düşündükleri (Ayaz vd., 2009; Çetin, 2009: 29; Gabriel vd., 2011) istihdamın sezon sonu azalması (İçöz ve Kozak, 2002) olduğunu belirtilmiştir. 


\section{Turizm ve Rekreasyon Faaliyetlerinin Yerel Halk Üzerinde Sosyo-Kültürel Etkileri}

Turizm ve rekreatif faaliyetler sonucu destinasyonda sosyo kültürel anlamda değişimlerde söz konusu olmaktadır. Getz (2008:407)' göre destinasyonda yapılan faaliyetler turizme destek olmakta, kentte yenilik yaşatmakta, ulusal benliği harekete geçirmekte ve kültürel olarak gelişmeyi sağlamaktadır. Turizm destinasyonunda yapılan faaliyetlerin sosyo- kültürel yönden olumlu ve olumsuz etkileri olduğu bilinmektedir. Kültürel ve sosyal açıdan sonuçları içerisinde halkın yeni insanlarla tanışma ve farklı kültürleri tanıma, yabancı dil öğrenme, örf ve adetlerinin öğrenilmesi, yeni yaşam biçimi oluşturma, inançlarına ve değer yargılarına saygı duyulması gibi olumlu sonuçları bulunmaktadır. Turizmin sebep olduğu olumsuz sonuç olarak trafik sıkışıklığı, park sorunu, suç işlemede artış olması, uyuşturucu madde kullanımı, yapan madde kullanımı, alkol tüketiminin artması, ahlakın bozulması arasında yer almaktadır (Bestard ve Nadal, 2007).

Yapılan çalışmalar sonucu turizm bölgesinde yaşayan yerel halkın turizm ve rekreatif faaliyetlerden olumlu sonuç olarak, yabancı milletlere ve kültürlerine saygı duymaya ve yabancı dil öğrenmeye (Doğan ve Üngüren, 2010), yöredeki eski mesleklerin tekrar icra edilmesine, kültürel etkinliklerin artmasına, yöreye ait ürünlerin değerinin artmasına katkısı olduğu (Kervankıran, 2014) belirlenmiştir. Olumsuz etki olarak; kültür, örf ve adetlerin yozlaşması (Diedrich ve Buades, 2009), suç oranında artış olduğu (Çelikkanat, 2014: 49), uyuşturucu madde kullanımının yaygınlaştığı, fazla alkol tüketiminin olduğu (Göktaş, 2016), ahlâki değerlerin azaldığı, yöredeki ticari ahlâkın bozulduğu (Keskin ve Contu, 2011), eğlence kulüplerinin açılmasıyla birlikte yerel halkın ahlakının bozulduğu sonucuna varılmıştır.

\section{Turizm ve Rekreasyon Faaliyetlerinin Yerel Halk Üzerinde Çevresel Etkileri}

Çevrenin insan yaşamındaki büyük öneminin yanında bir turizm destinasyonu hakkında turizm talebinin olması ve bu talebin devamlılığının olması yönünden önemlidir. Çünkü turizm doğal, kültürel ve tarihi kaynaklarla var olan bir sektördür. Doğal kaynakların varlığı rekreasyon ve turizm faaliyetleri için başlıca etkinlik öğesi olmaktadır (Karaküçük ve Akgül, 2016: 195). Bundan dolayı kaynakların korunması turizm ve aynı kaynaklardan yararlanan rekreatif faaliyetlerin sürdürülebilirliği açısından önemlidir. Bu durum turizm ve rekreasyon faaliyetlerinin kaynakları kullanırken aynı zamanda kaynakları koruma zorunluluğunu getirmektedir.

Bu konuda bölge halkının görüşlerini almaya yönelik birçok çalışma yapılmıştır. Turizm ve rekreasyon faaliyetlerinin yarattığı başlıca olumsuz çevresel etkiler arasında alan kullanım sorunları (Sarı,1991:169), doğal çevrenin tahrip edilmesi, görsel anlamda kalitesizleşme, hava, su, toprak ve gürültü kirliliği yaratılması, turistik ürün ve hizmet tüketimi sonrası ortaya çıkan zararlı atıklar (Oğuz 1991:170; Örücü 2002:136), aşırı nüfus, plansız kentleşme, flora ve faunaya zarar verilip biyo çeşitliliğin bozulması, aşırı şekilde doğal kaynakların tüketimi (Karaküçük ve Akgül, 2016: 194) tarihi alanlara zarar verilmesi, yolların bozulması, tarım alanlarının verimsizleşmesi bulunmaktadır. Inskeep (1991: 344) turizmin çevresel olumsuz etkilerini su, hava, gürültü ve kirlilik, katı atık kirliliği, ekolojinin bozulması, erozyon, sel vb. sorunlar, tarihi bölgelerin zarara uğraması ve arazi kullanımı problemleri olarak belirtmiştir. Etkiler arasında halk bölgenin turizmin etkisiyle kentleşmesiyle birlikte kırsallıktan çıkıp doğanın bozulmasına neden olması (Çalışkan ve Tütüncü, 2008), trafik sorunu olması, kirliliğin artması (İçöz ve Kozak (2002), tarihi ve arkeolojik alanların zarar görmesi (Inskeep,1991), plajlarda ve denizde meydana gelen kirlilikler (Dal ve Baysan, 2007) belirtilmiştir.

Ekolojik anlamda sürdürülebilir faaliyetler düzensiz ve kötü planlanmış şekilde yapıldığ 1 takdirde çevresel etkilerin olumsuz olması muhtemeldir (Panizzon ve Boulton, 2000). Turizm ve 
rekreasyonel faaliyetlerinin çevrede yarattığı olumsuz sonuçların önlenmesi için yerel yönetimler ve hükümet tarafından olumsuz etkiler tespit edilmeli, bu faaliyetlerin yapılma alanlarının düzenlenmesi ve sınırlandırılması için gerekli önlemler alınmalı, doğal, kültürel ve tarihi alanların devamlılığı sağlanmalıdır.

Yapılan çalışmalardan çıkan sonuca göre, turizm ve rekreasyon faaliyetlerinin olumlu ve olumsuz etkileri bulunmakta ve bu etkiler doğrudan destinasyonda yaşayan halkı etkilemektedir.

\section{YÖNTEM}

\section{Araştırmanın Evreni ve Örneklemi}

Araştırmanın evrenini Kapadokya Bölgesi içerisinde yer alan Nevşehir ilinde yaşayan yerel halk oluşturmaktadır. Araştırmanın örneklemini Nevşehir'de ikamet eden 22 kişi oluşturmaktadır.

\section{Veri Toplama Yöntemi}

Çalışmada veri toplama yöntemi olarak konusunda uzman araştırmacılar tarafından hazırlanan sorular yer almaktadır. Çalışma kapsamında hazırlanan sorular katılımcıların demografik özelliklerine yönelik soruları, boş zaman değerlendirme faaliyetlerine ilişkin soruları ve turistlerin destinasyona gelmesinin yerel halk açısından etkisini belirlemeye yönelik soruları içermektedir.

\section{Verilerin Toplanması}

Nitel bir araştırma olan çalışmanın verileri Kapadokya Bölgesi merkezi sayılan Nevşehir şehir merkezinde yaşayan yerli halkla görüşme sonrası elde edilmiştir. Görüşmeler 2019 Aralık ayı içerisinde gerçekleştirilmiş olup her bir katılımcıya mülakat tekniğiyle toplanmıştır. Yüz yüze yapılan mülakatların her biri yaklaşık bir saat sürmüştür. Elde edilen veriler, bilgisayar ortamında Word dosyası şeklinde kaydedilip verilerin depolanması sağlanmıştır.

\section{Verilerin Analizi}

Verilerin analiz edilmesinde; araştırmacılar öncelikle görüşme verilerini özen ve titizlik içerisinde dikkatli şekilde okuyup incelemiştir. Veriler çalışmaya katılan bireyler Katılımcı 1 (K1), Katılımcı 2 (K2), ... şeklinde kodlanmıştır. Veriler içeriklerine göre içerik analiz tekniği ile analiz edilmiştir. Sonrasında elde edilen veriler sınıflandırılmış olup, bu sınıflandırılmış verilerden temalar oluşturulmuştur. Turistlerin etkisi ile ilgili bulguların tema oluşturma aşamasında analizinde Ko ve Stewart (2002) ve Şahbaz (2015: 229) çalışmasında yaptığı sınıflandırmalardan yararlanılmıştır. Sonrasında bulgular tanımlanarak çalışma yorumlanmıştır.

\section{BULGULAR}

Çalışma bulguları yerel halkın demografik özellikleri ve rekreatif faaliyetlere karşı algılarına yönelik bulgular şeklinde ayrılmaktadır. K1, K2,K3, ... katılımcı sırasını ifade etmektedir. 


\section{Demografik Özelliklere İlişkin Bulgular}

Tablo 1. Katılımcıların Cinsiyet, Yaş, Eğitim, Gelir Durumu, Meslek ve İkamet Süresini İçeren Bulgular

\begin{tabular}{|l|l|l|l|l|l|l|}
\hline Katılımcılar & Cinsiyet & Yaş & $\begin{array}{l}\text { Eğitim } \\
\text { Durumu }\end{array}$ & $\begin{array}{l}\text { Gelir } \\
\text { Algılaması }\end{array}$ & Meslek & $\begin{array}{l}\text { Íkamet } \\
\text { Süresi/yıl }\end{array}$ \\
\hline K1 & Erkek & 45 & Lise & Düşük & Esnaf & 45 \\
\hline K2 & Kadın & 42 & Lise & Düşük & Ev hanımı & 42 \\
\hline K3 & Erkek & 39 & Lisans & Orta & Öğretmen & 3 \\
\hline K4 & Erkek & 50 & Lisans & Yüksek & Memur & 12 \\
\hline K5 & Erkek & 40 & Lisans & Orta & Oto kiralamac1 & 14 \\
\hline K6 & Erkek & 66 & İlkokul & Düşük & Çiftçi & 66 \\
\hline K7 & Kadın & 27 & Lise & Düşük & Garson & 27 \\
\hline K8 & Kadın & 48 & İlkokul & Düşük & Esnaf & 26 \\
\hline K9 & Erkek & 34 & Lisans & Düşük & Esnaf & 11 \\
\hline K10 & Erkek & 27 & Lisans & Orta & Öğretmen & 5 \\
\hline K11 & Erkek & 38 & Lisans & Düşük & Memur & 8 \\
\hline K12 & Erkek & 34 & Lise & Yüksek & Esnaf & 22 \\
\hline K13 & Kadın & 22 & Lise & Orta & Öğrenci & 4 \\
\hline K14 & Kadın & 54 & Ortaokul & Orta & Ev hanımı & 54 \\
\hline K15 & Kadın & 34 & Ortaokul & Orta & Serbest meslek & 8 \\
\hline K16 & Kadın & 32 & Lisansüstü & Orta & Akademisyen & 7 \\
\hline K17 & Erkek & 62 & İlkokul & Orta & Esnaf emeklisi & 45 \\
\hline K18 & Erkek & 49 & Lise & Yüksek & Serbest meslek & 32 \\
\hline K19 & Kadın & 48 & Lisans & Yüksek & Turist rehberi & 15 \\
\hline K20 & Kadın & 51 & Ortaokul & Düşük & Esnaf & 51 \\
\hline K21 & Erkek & 35 & Lisans & Orta & Polis memuru & 8 \\
\hline K22 & Erkek & 21 & Lise & Düşük & Öğrenci & 3 \\
\hline & & & & & \\
\hline
\end{tabular}

Tablo 1' de çalışmaya katılan bireylerin cinsiyeti, yaşı eğitim durumu, gelir algılamaları, mesleği ve bölgede ikamet ettiği yıl hakkında bilgiler yer almaktadır.

Tablo 2'ye göre çalışmaya katılan bireylerin \% 59,09'unun erkek, \% 40,91' inin ise kadın olduğu görülmüştür. Katılımcıların yaş bulgularına göre, \% 27,27'sinin 28-37 yaş arasında, \% 22,72'sinin 38-47 ve 48-57 yaş arası,\%18,19'unun 18-27 yaş arası, \% 9,1'inin 58-67 yaş aralığında olduğu belirlenmiştir. Katılımcıların mesleklerine ilişkin bulgularda, \% 27,27'sinin memur ve esnaf, \% 13,63'ünün serbest meslek, \% 9,1'inin ev hanımı, özel sektör çalışanı ve öğrenci olduğu, \% 4,54'ünün ise emekli olduğu belirlenmiştir. Katılımclların gelir durumu algılarında ise, \% 45,46 düşük seviye, \%40,91 orta seviye, \% 13,63 ‘ünün ise yüksek seviye algıladıkları tespit edilmiştir. Katılımcların eğitim durumu bulgularında ise, \% 31,81'inin lisans, \% 27,27'sinin lise, \% 18,19 'unun ortaokul, \% 13,63 ilkokul, \% 9,1'inin ise lisansüstü mezunu olduğu görülmüştür. Bölgede ikamet ettiği yıl bulgularına göre katılımcıların \%40,91'inin 1-10 yıl arası, \% 13,63'ünün 11-20 yıl arası,21-30 yıl arası ve 41-50 yıl arası, \% 9,1'inin 51-60 yıl arası, \% 4,54'ünün ise 31-40 yıl arası ve 61-70 yıl arası olduğu belirlenmiştir. 
Tablo 2. Katılımcıların Demografik Bilgilerinin Frekans ve Yüzde Dağılımları

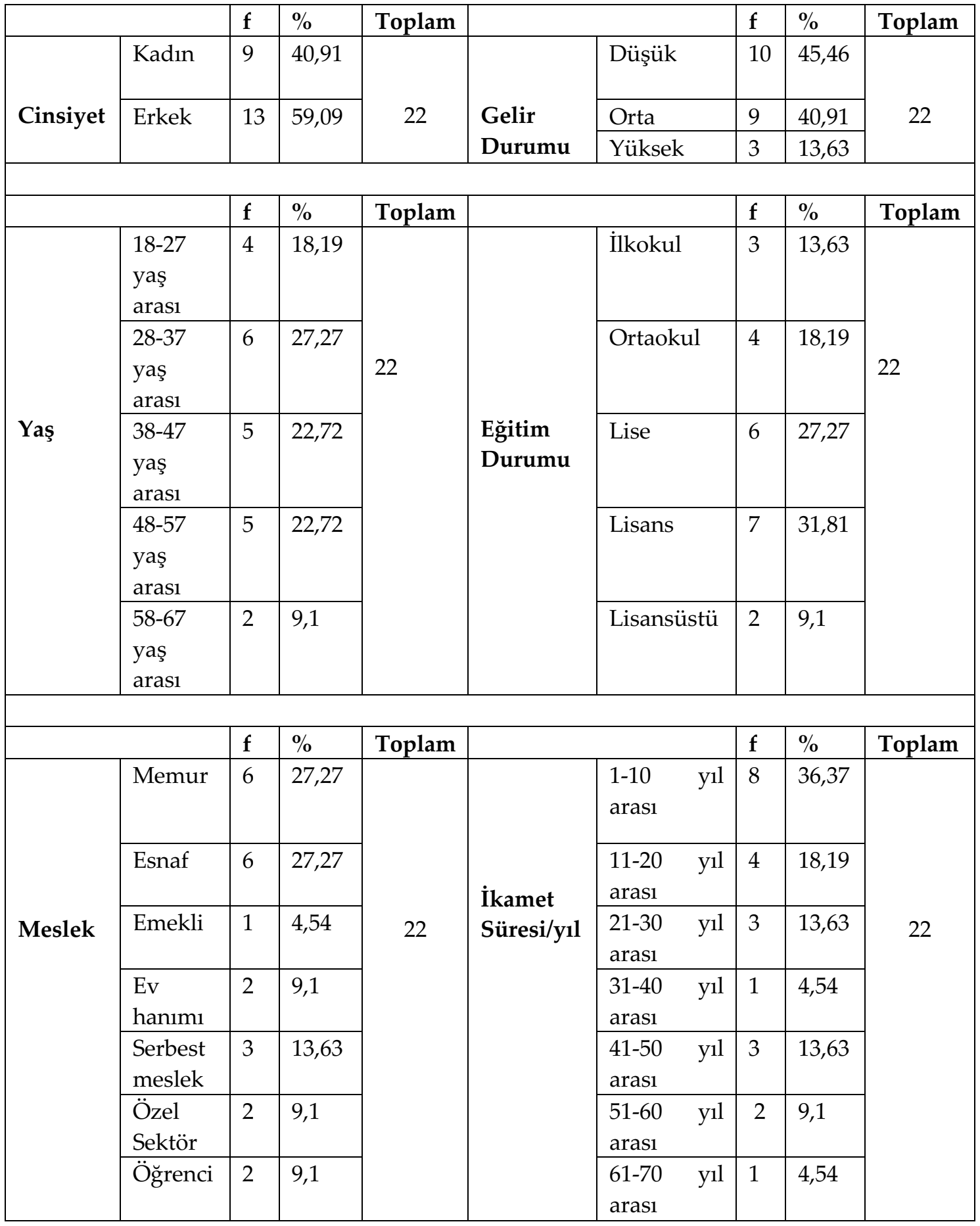

\section{Rekreatif Faaliyetlere Karşı Algılarına Yönelik Bulgular}

Tablo 3'te görüldüğü gibi boş zaman aktivitesi olarak katılımcıların en çok \% 59,09 oranla TV izleme ve bölgeyi gezme, \% 45,45 ile ev ziyareti, \%36,36 ile spor yapma olduğu belirlenmiştir. 
Tablo 3. Katılımcıların Boş Zamanları Değerlendirme Biçimleri

\begin{tabular}{|l|l|l|l|l|}
\hline $\begin{array}{l}\text { Boş Zaman Değerlendirme } \\
\text { Aktiviteleri }\end{array}$ & \multicolumn{1}{|c|}{ Katılımc1lar } & f & Toplam \\
\hline TV izleme & $\begin{array}{l}\mathrm{K} 1, \mathrm{~K} 2, \mathrm{~K} 4, \mathrm{~K} 5, \mathrm{~K} 8, \mathrm{~K} 9, \mathrm{~K} 10, \\
\mathrm{~K} 11, \mathrm{~K} 13, \mathrm{~K} 14, \mathrm{~K} 20, \mathrm{~K} 21, \mathrm{~K} 22\end{array}$ & 13 & 59,09 & 22 \\
\hline Müzik dinleme & $\mathrm{K} 5, \mathrm{~K} 9, \mathrm{~K} 13, \mathrm{~K} 19, \mathrm{~K} 21, \mathrm{~K} 22$ & 6 & 27,27 & 22 \\
\hline Ev ziyareti & $\mathrm{K} 2, \mathrm{~K} 7, \mathrm{~K} 8, \mathrm{~K} 9, \mathrm{~K} 12, \mathrm{~K} 13, \mathrm{~K} 14, \mathrm{~K} 15, \mathrm{~K} 17, \mathrm{~K} 20$ & 10 & 45,45 & 22 \\
\hline Sinemaya gitme & $\mathrm{K} 3, \mathrm{~K} 4, \mathrm{~K} 9, \mathrm{~K} 16, \mathrm{~K} 19, \mathrm{~K} 21$ & 6 & 27,27 & 22 \\
\hline Bölgeyi gezme & $\mathrm{K} 1, \mathrm{~K} 2, \mathrm{~K} 3, \mathrm{~K} 4, \mathrm{~K} 5, \mathrm{~K} 6, \mathrm{~K} 9, \mathrm{~K} 10, \mathrm{~K} 11, \mathrm{~K} 12,, \mathrm{~K} 13$, & 13 & 59,09 & 22 \\
& $\mathrm{~K} 15, \mathrm{~K} 19$ & & & \\
\hline El işi yapma (Örgü, dantel) & $\mathrm{K} 8, \mathrm{~K} 15, \mathrm{~K} 20$ & 3 & 13,63 & 22 \\
\hline Kahvehaneye gitme & $\mathrm{K} 17$ & 1 & 4,54 & 22 \\
\hline Spor yapma & $\mathrm{K} 1, \mathrm{~K} 6, \mathrm{~K} 7, \mathrm{~K} 10, \mathrm{~K} 11, \mathrm{~K} 12, \mathrm{~K} 16, \mathrm{~K} 21$ & 8 & 36,36 & 22 \\
\hline Piknik yapma & $\mathrm{K} 2, \mathrm{~K} 14, \mathrm{~K} 17$ & 3 & 13,63 & 22 \\
\hline Kitap okuma & $\mathrm{K} 3, \mathrm{~K} 16, \mathrm{~K} 19, \mathrm{~K} 21$ & 4 & 18,18 & 22 \\
\hline Kafe/Avm Gitme & $\mathrm{K} 7, \mathrm{~K} 10, \mathrm{~K} 14, \mathrm{~K} 20, \mathrm{~K} 22$ & 5 & 22,72 & 22 \\
\hline Bahçe-bağla ilgilenme & $\mathrm{K} 1, \mathrm{~K} 2, \mathrm{~K} 14, \mathrm{~K} 17, \mathrm{~K} 18$ & 5 & 22,72 & 22 \\
\hline Hamama gitme & $\mathrm{K} 2, \mathrm{~K} 17$ & 2 & 9,09 & 22 \\
\hline Resim yapma & $\mathrm{K} 4, \mathrm{~K} 21$ & 2 & 9,09 & 22 \\
\hline Turizm/Seyahat etme & $\mathrm{K} 5$ & 1 & 4,54 & 22 \\
\hline Hayvan besleme & $\mathrm{K} 6$ & 1 & 4,54 & 22 \\
\hline Konser/etkinlik katılma & $\mathrm{K} 7$ & 1 & 4,54 & 22 \\
\hline $\begin{array}{l}\text { El sanatiyla ilgilenme (çömlek, } \\
\text { seramik...) }\end{array}$ & $\mathrm{K} 12, \mathrm{~K} 19$ & 2 & 9,09 & 22 \\
\hline & & & & \\
\hline
\end{tabular}

Tablo 3. Katılımcıların Kapadokya Bölgesi'ni Ziyaret Eden Turistler Katıldığı Aktivite Hakkında Görüşleri

\begin{tabular}{|c|c|c|c|c|}
\hline $\begin{array}{ll}\text { Bölgede } & \text { Yapilan } \\
\text { Faaliyetler } & \\
\end{array}$ & Katılımcilar & f & $\%$ & Toplam \\
\hline $\begin{array}{lll}\text { Sicak Hava } & \text { Balonu } \\
\text { Seyahati } & & \\
\end{array}$ & $\begin{array}{l}\mathrm{K} 1, \mathrm{~K} 2, \mathrm{~K} 3, \mathrm{~K} 4, \mathrm{~K} 5, \mathrm{~K} 6, \mathrm{~K} 7, \mathrm{~K} 8, \mathrm{~K} 9, \mathrm{~K} 10, \mathrm{~K} 11, \mathrm{~K} 12, \mathrm{~K} 13, \mathrm{~K} 14, \mathrm{~K} \\
15, \mathrm{~K} 16, \mathrm{~K} 17, \mathrm{~K} 18, \mathrm{~K} 19, \mathrm{~K} 20, \mathrm{~K} 21, \mathrm{~K} 22\end{array}$ & 22 & 100 & 22 \\
\hline At Binme & $\mathrm{K} 2, \mathrm{~K} 3, \mathrm{~K} 4, \mathrm{~K} 5, \mathrm{~K} 6, \mathrm{~K} 11, \mathrm{~K} 16, \mathrm{~K} 19, \mathrm{~K} 21$ & 9 & 40,90 & 22 \\
\hline Bisiklete Binme & $\mathrm{K} 5, \mathrm{~K} 13, \mathrm{~K} 15, \mathrm{~K} 19, \mathrm{~K} 21$ & 5 & 22,72 & 22 \\
\hline ATV Turu & $\begin{array}{l}\text { K1,K2,K3,K4,K5,K6,K9,K11,K13,K16,K17,K19,K20,K21 } \\
\text {,K22 }\end{array}$ & 15 & 68,18 & 22 \\
\hline Günlük Bölge Turu & $\begin{array}{l}\mathrm{K} 1, \mathrm{~K} 2, \mathrm{~K} 4, \mathrm{~K} 5, \mathrm{~K} 6, \mathrm{~K} 7, \mathrm{~K} 8, \mathrm{~K} 9, \mathrm{~K} 10, \mathrm{~K} 11, \mathrm{~K} 12, \mathrm{~K} 13, \mathrm{~K} 14, \mathrm{~K} 15, \\
\mathrm{~K} 18, \mathrm{~K} 19, \mathrm{~K} 20, \mathrm{~K} 21, \mathrm{~K} 22\end{array}$ & 19 & 86,36 & 22 \\
\hline Vadi Yürüyüşü & $\mathrm{K} 3, \mathrm{~K} 4, \mathrm{~K} 6, \mathrm{~K} 7, \mathrm{~K} 8, \mathrm{~K} 19$ & 6 & 27,27 & 22 \\
\hline Çömlek Yapımı & $\mathrm{K} 2, \mathrm{~K} 3, \mathrm{~K} 5, \mathrm{~K} 11, \mathrm{~K} 13, \mathrm{~K} 14, \mathrm{~K} 15, \mathrm{~K} 17, \mathrm{~K} 19, \mathrm{~K} 21, \mathrm{~K} 22$ & 11 & 50 & 22 \\
\hline Seramik Yapımı & K10 & 1 & 4,54 & 22 \\
\hline Türk Gecesi & $\mathrm{K} 1, \mathrm{~K} 2, \mathrm{~K} 5, \mathrm{~K} 10, \mathrm{~K} 11, \mathrm{~K} 12, \mathrm{~K} 14, \mathrm{~K} 19, \mathrm{~K} 20, \mathrm{~K} 22$ & 10 & 45,45 & 22 \\
\hline Türk Hamamı & $\mathrm{K} 2, \mathrm{~K} 10, \mathrm{~K} 13, \mathrm{~K} 17, \mathrm{~K} 19, \mathrm{~K} 22$ & 6 & 27,27 & 22 \\
\hline Kaplica & K11 & 1 & 4,54 & 22 \\
\hline Gondol, Tekne Gezisi & $\mathrm{K} 4, \mathrm{~K} 8, \mathrm{~K} 17$ & 3 & 13,63 & 22 \\
\hline $\begin{array}{l}\text { Halı, Deri, Seramik } \\
\text { Alışverişi }\end{array}$ & $\mathrm{K} 3, \mathrm{~K} 10, \mathrm{~K} 14, \mathrm{~K} 19, \mathrm{~K} 22$ & 5 & 22,72 & 22 \\
\hline Yeme-içme & K3,K15 & 2 & 9,09 & 22 \\
\hline Bar/diskoda Eğlenme & K11 & 1 & 4,54 & 22 \\
\hline
\end{tabular}


Çalışma bulgularına göre katılımcıların \%100'ü Kapadokya Bölgesi'ni ziyaret eden turistlerin katıldığı aktiviteler arasında sıcak hava balonu olduğunu belirtmiştir. Bunun yanında katılımcılar en çok \%86,36 günlük bölge turu, $\% 68,18$ ATV turu, $\% 45,45$ Türk gecesi etkinliğine katıldığını belirtmiştir.

Tablo 4. Katılımcıların Bölgeye Özgü Turizm Faaliyetlerine Katılma Durumları

\begin{tabular}{|l|l|l|l|l|}
\hline $\begin{array}{l}\text { Katılma } \\
\text { Durumlar1 }\end{array}$ & Katılımc1lar & $\mathbf{f}$ & $\mathbf{\%}$ & Toplam \\
\hline Evet & $\mathrm{K} 2, \mathrm{~K} 3, \mathrm{~K} 4, \mathrm{~K} 5, \mathrm{~K} 6, \mathrm{~K} 9, \mathrm{~K} 11, \mathrm{~K} 12, \mathrm{~K} 16, \mathrm{~K} 17, \mathrm{~K} 19, \mathrm{~K} 21$ & 12 & 54,54 & 22 \\
\hline Hayır & $\mathrm{K} 1, \mathrm{~K} 7, \mathrm{~K} 8, \mathrm{~K} 10, \mathrm{~K} 13, \mathrm{~K} 14, \mathrm{~K} 15, \mathrm{~K} 18, \mathrm{~K} 20, \mathrm{~K} 22$ & 10 & 45,46 & 22 \\
\hline
\end{tabular}

Tablo 4 'teki çalışma bulgularına göre katılımcıların 54,54'ü bölgede yapılan turizm faaliyetlerine katılma fırsatı bulabildiğini, \%45,46'sı ise turizm faaliyetlerine katılma fırsatı bulamadığını belirtmiştir.

Tablo 5. Katılımcıların Bölgede Yapılan Turizm Faaliyetlerine Katılımı

\begin{tabular}{|l|l|l|l|l|}
\hline Bölgede Yapılan Faaliyetler & \multicolumn{1}{|c|}{ Katılımcılar } & \multicolumn{1}{c|}{ f } & \multicolumn{1}{c|}{ Toplam } \\
\hline Sicak Hava Balonu Seyahati & $\mathrm{K} 2, \mathrm{~K} 4, \mathrm{~K} 5, \mathrm{~K} 6, \mathrm{~K} 16, \mathrm{~K} 19, \mathrm{~K} 21$ & 7 & 58,33 & 12 \\
\hline At Binme & $\mathrm{K} 5, \mathrm{~K} 11, \mathrm{~K} 19$, & 3 & 25 & 12 \\
\hline Bisiklete Binme & $\mathrm{K} 3$ & 1 & 8,33 & 12 \\
\hline ATV Turu & $\mathrm{K} 2, \mathrm{~K} 5, \mathrm{~K} 6, \mathrm{~K} 16, \mathrm{~K} 19, \mathrm{~K} 21$ & 6 & 50 & 12 \\
\hline Bölge Turu & $\mathrm{K} 5, \mathrm{~K} 9$ & 2 & 16,66 & 12 \\
\hline Vadi Yürüyüşü & $\mathrm{K} 2, \mathrm{~K} 4, \mathrm{~K} 5, \mathrm{~K} 6, \mathrm{~K} 9, \mathrm{~K} 11, \mathrm{~K} 19, \mathrm{~K} 21$ & 8 & 66,66 & 12 \\
\hline Çömlek Yapımı & $\mathrm{K} 2, \mathrm{~K} 5, \mathrm{~K} 6, \mathrm{~K} 11, \mathrm{~K} 17, \mathrm{~K} 19$ & 6 & 50 & 12 \\
\hline Türk Gecesi & $\mathrm{K} 5, \mathrm{~K} 19, \mathrm{~K} 21$ & 3 & 25 & 12 \\
\hline Türk Hamam1 & $\mathrm{K} 2, \mathrm{~K} 17, \mathrm{~K} 19$, & 3 & 25 & 12 \\
\hline Bar/diskoda eğlenme & $\mathrm{K} 19$ & 1 & 8,33 & 12 \\
\hline Festival & $\mathrm{K} 3, \mathrm{~K} 12$ & 2 & 16,66 & 12 \\
\hline Sergi & $\mathrm{K} 12$ & 1 & 8,33 & 12 \\
\hline
\end{tabular}

Tablo 5 'te görüldügüu gibi, en çok katılımcıların $\% 66,66$ 's1 vadi yürüyüşü, $\% 58,33^{\prime}$ ü sıcak hava balonu seyahati, \% 50'si ATV turu ve çömlek yapımı, \%25'i ata binme, Türk gecesi ve Türk hamamı faaliyetlerine katıldığı belirlenmiştir.

Tablo 6' da turistlerin bölgeye gelmesinin yerel halk için olumlu sonuç bulguları yer almaktadır.

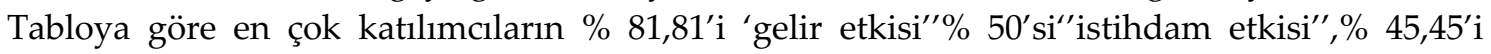
bölgeyi tanıtma" \%36,36'sı "farklı kültürleri tanıma" şeklide olumlu etkisi olduğunu belirtmiştir. 
Tablo 6. Katılımcılar Açısından Turistlerin Bölgeye Gelmesinin Yerel Halk İçin Olumlu Sonuçları

\begin{tabular}{|c|c|c|c|c|}
\hline Olumlu Sonuçlar & Katılımcilar & $\mathbf{f}$ & $\%$ & $\begin{array}{c}\text { Topla } \\
\text { m }\end{array}$ \\
\hline Gelir etkisi & $\begin{array}{l}\text { K1, K2, K5,K7, K8, K9, K10, K11, } \\
\text { K12,K13,K14,K15,K16,K17,K18,K1 } \\
\text { 9,K20,K21 }\end{array}$ & 18 & $\begin{array}{l}81,8 \\
1\end{array}$ & 22 \\
\hline İstihdam etkisi & $\begin{array}{l}\text { K1, K5, K6, K7, K13, K14, K16,K17, } \\
\text { K19,K20,K22, }\end{array}$ & 11 & 50 & 22 \\
\hline Ek gelir sağlama & K6, K19 & 2 & 9,09 & 22 \\
\hline Bölgeyi tanitma & $\begin{array}{l}\text { K2,K4，K8，K10，K11，K13,K14， } \\
\text { K15,K19,21 }\end{array}$ & 10 & $\begin{array}{l}45,4 \\
5 \\
\end{array}$ & 22 \\
\hline Örf ve adetleri tanitma & K18,K19 & 2 & 9,09 & 22 \\
\hline Dil öğrenme & K19,K22 & 2 & 9,09 & 22 \\
\hline Farklı kültürleri tanıma & K3, K4, K6, K9, K10, K11, K12, ,K22 & 8 & $\begin{array}{l}36,3 \\
6\end{array}$ & 22 \\
\hline Sosyal ilişkiler kurma & K9, K11, K22 & 3 & $\begin{array}{l}13,6 \\
3\end{array}$ & 22 \\
\hline Şehire canlılık katması & $\mathrm{K} 1, \mathrm{~K} 2$, & 2 & 9,09 & 22 \\
\hline Bölgeyi kalkındırma & K3, K4,K17 & 3 & $\begin{array}{l}13,6 \\
3\end{array}$ & 22 \\
\hline $\begin{array}{l}\begin{array}{l}\text { Konser, festival, etkinlik } \\
\text { düzenlenme }\end{array} \\
\end{array}$ & K3 & 1 & 4,54 & 22 \\
\hline İ̀s/staj olanaklarının artması & K13 & 1 & 4,54 & 22 \\
\hline Bölgeye yatırımın artması & K17 & 1 & 4,54 & 22 \\
\hline $\begin{array}{lll}\begin{array}{l}\text { Bölgede } \\
\text { artırması özgüveni, }\end{array} & \text { gurur } \\
\end{array}$ & K13, K6, K19 & 3 & $\begin{array}{l}13,6 \\
3\end{array}$ & 22 \\
\hline
\end{tabular}

Tablo 7. Katılımcıların Turistlerin Bölgeye Gelmesinin Yerel Halk İçin Olumsuz Sonuçları Olma Durumu

\begin{tabular}{|l|l|l|l|l|}
\hline Olumsuz sonu & \multicolumn{1}{|c|}{ Kat1lımc1lar } & F & \% & Toplam \\
\hline Var & $\mathrm{K} 2, \mathrm{~K} 4, \mathrm{~K} 13, \mathrm{~K} 14, \mathrm{~K} 16, \mathrm{~K} 17, \mathrm{~K} 19, \mathrm{~K} 21$ & 8 & 36,37 & 22 \\
\hline Yok & $\begin{array}{l}\mathrm{K} 1, \mathrm{~K} 3, \mathrm{~K} 5, \mathrm{~K} 6, \mathrm{~K} 7, \mathrm{~K} 8, \mathrm{~K} 9, \mathrm{~K} 10, \mathrm{~K} 11, \mathrm{~K} 12, \mathrm{~K} 15, \\
\mathrm{~K} 20, \mathrm{~K} 22\end{array}$ & 14 & 63,63 & 22 \\
\hline
\end{tabular}

Çalışma bulgularında katılımcıların \% 63,67'sinin bölgeye gelen turistten olumsuz bir algılama oluşmadığı, \% 36,37'sinin turistten olumsuz bir alg1 oluştuğu görülmüş̧tür.

Tablo 8'de görüldügüü gibi katılımcların \% 100'ü turistlerin bölgeye gelmenin olumsuz sonucu olarak "fiyat pahalılığı yaratması" olarak belirtmiştir. Katılımcıların \% 37,5'i "kültürel kimlik, gelenekler ve bölgesel karakterlerde yozlaşma" ve "sosyal eşitsizlik oluşturabilme", \% 25' i "alkol ve uyuşturucu kullanımını artırması", \% 17,5'i "ahlaki değerleri bozması", suç oranlarını artırması" ve doygunluk ve taşıma kapasitesinin aşılması" olarak belirtmiştir. 
Tablo 8. Katılımcılar Açısından Turistlerin Bölgeye Gelmesinin Yerel Halk İçin Olumsuz Sonuçları

\begin{tabular}{|l|l|l|l|l|}
\hline Olumsuz Sonuçlar & \multicolumn{1}{|c|}{ Katılımcılar } & \multicolumn{1}{|c|}{ f } & \multicolumn{1}{|c|}{ Toplam } \\
\hline Fiyat pahalılı̆ı yaratması & $\begin{array}{l}\text { K2, K4, K13,K14, } \\
\text { K16,K17,K19, K21 }\end{array}$ & 8 & 100 & 8 \\
\hline $\begin{array}{l}\text { Kültürel kimlik, gelenekler ve bölgesel } \\
\text { karakterlerde yozlaşma }\end{array}$ & K4, K14, K16,K19 & 3 & 37,5 & 8 \\
\hline Ahlaki değerleri bozması & K4 & 1 & 17,50 & 8 \\
\hline Sosyal eşitsizlik oluşturabilmesi & K2, K13, K19 & 3 & 37,5 & 8 \\
\hline Alkol ve uyuşturucu kullanımını artırması & $\mathrm{K} 19, \mathrm{~K} 21$ & 2 & 25 & 8 \\
\hline $\begin{array}{l}\text { Suç oranlarını artırması (hırsızlık, kaçakçılık, } \\
\text { taciz, vandalizm..) }\end{array}$ & $\mathrm{K} 21$ & 1 & 17,50 & 8 \\
\hline $\begin{array}{l}\text { Doygunluk ve Taşıma Kapasitesinin Aşılması } \\
\text { (Trafik, Kalabalı) }\end{array}$ & $\mathrm{K} 4$ & 1 & 17,50 & 8 \\
\hline
\end{tabular}

Tablo 9. Katılımcılar Açısından Bölgede Turizm Faaliyetlerinin Yapılmasından Rahatsız Olma Durumları

\begin{tabular}{|l|l|l|l|l|}
\hline Rahatsızlık Durumu & Katılımcılar & f & \% & Toplam \\
\hline Evet & \multicolumn{1}{|c|}{-} & 0 & 0 & 22 \\
\hline Hayır & $\begin{array}{l}\text { K1,K2,K3,K4,K5,K6,K7,K8,K9,K10,K11, } \\
\text { K12,K13,K14,K15,K16,K17,K18,K19,K20, } \\
\text { K21,K22 }\end{array}$ & 22 & 100 & 22 \\
\hline
\end{tabular}

Tablo 9'daki çalışma bulgularında katılımcıların \%100'ünün bölgede yapılan turizm faaliyetlerinden rahatsız olmadığı görülmüştür.

Tablo 10. Bölgede Yapılan Turistik Faaliyetlerin Eksiklikleri

\begin{tabular}{|c|c|c|c|c|}
\hline Eksiklikler & Katılımcılar & $\mathbf{f}$ & $\%$ & Toplam \\
\hline Fiyat Pahalılığı & $\begin{array}{l}\mathrm{K} 2, \mathrm{~K} 3, \mathrm{~K} 5, \mathrm{~K} 6, \mathrm{~K} 10, \mathrm{~K} 12, \mathrm{~K} 13 \\
\text {,K15,K17,K20,K21,K22 }\end{array}$ & 12 & 54,54 & 22 \\
\hline $\begin{array}{l}\text { Balon gazlarının doğal alanlara ve } \\
\text { çevreye zararları }\end{array}$ & K15, K22 & 2 & 14,14 & 22 \\
\hline $\begin{array}{l}\text { Faaliyet alanında } \\
\text { kapasitesinin aşılması }\end{array}$ & K16, K19, & 2 & 14,14 & 22 \\
\hline $\begin{array}{l}\text { Çevreye uyumsuz modern faaliyet } \\
\text { yapiların yapılması }\end{array}$ & K9, K18,K21 & 3 & & 22 \\
\hline $\begin{array}{l}\text { Faaliyet düzenleyenlerin yabancı dil } \\
\text { bilme sorunu }\end{array}$ & $\mathrm{K} 1, \mathrm{~K} 10$ & 2 & 14,14 & 22 \\
\hline Trafik sorunu yaratması & K2 & 1 & 7,7 & 22 \\
\hline Faaliyet saatlerinin sınırlı olması & K2, K13 & 2 & 14,14 & 22 \\
\hline $\begin{array}{l}\text { Faaliyetlerin yapılması aşamasında } \\
\text { doğal alanların korunmaması }\end{array}$ & K1, K15, K19, K21 & 4 & 18,18 & 22 \\
\hline Tanitım ve reklamin yetersiz olması & $\begin{array}{l}\mathrm{K} 3, \mathrm{~K} 5, \mathrm{~K} 8, \mathrm{~K} 11, \mathrm{~K} 14, \mathrm{~K} 21, \mathrm{~K} 2 \\
2\end{array}$ & 7 & 31,81 & 22 \\
\hline
\end{tabular}




\begin{tabular}{|l|l|l|l|l|}
\hline $\begin{array}{l}\text { Kalite açısından belli standartının } \\
\text { olmaması }\end{array}$ & $\mathrm{K} 3, \mathrm{~K} 12$ & 2 & 14,14 & 22 \\
\hline Fiyat tutarsızlı̆̆1 & $\mathrm{K} 3, \mathrm{~K} 21$ & 2 & 14,14 & 22 \\
\hline $\begin{array}{l}\text { Yerel halka yönelik faaliyetlerin } \\
\text { yapılmaması }\end{array}$ & $\mathrm{K} 4, \mathrm{~K} 13$ & 2 & 14,14 & 22 \\
\hline $\begin{array}{l}\text { Bölgenin kültürel özelliklerini tam } \\
\text { olarak yansıtamamaları }\end{array}$ & $\mathrm{K} 4$ & 1 & 7,7 & 22 \\
\hline Tabela eksikliği & $\mathrm{K} 7, \mathrm{~K} 11$ & 2 & 14,14 & 22 \\
\hline Yerel halkın katılımının engellenmesi & $\mathrm{K} 5, \mathrm{~K} 6, \mathrm{~K} 22$ & 3 & 13,63 & 22 \\
\hline $\begin{array}{l}\text { Aydınlatmaların olmaması /yetersiz } \\
\text { olması }\end{array}$ & $\mathrm{K} 7, \mathrm{~K} 13, \mathrm{~K} 22$ & 3 & 13,63 & 22 \\
\hline Faaliyetlere ulaşımın kötü olması & $\mathrm{K} 6$ & 1 & 7,7 & 22 \\
\hline Güvenlik önleminin olmaması & $\mathrm{K} 7$ & 1 & 7,7 & 22 \\
\hline Sadece ticari amaçla yapılması & $\mathrm{K} 19$ & 1 & 7,7 & 22 \\
\hline $\begin{array}{l}\text { Geceleme süresini daha da artıracak } \\
\text { aktivitelerin yapılmaması }\end{array}$ & $\mathrm{K} 16$ & 1 & 7,7 & 22 \\
\hline Faaliyetler denetlenmiyor & $\mathrm{K} 10$ & 1 & 7,7 & 22 \\
\hline Etkinlik çeşidinin azlığ1 & $\mathrm{K} 10, \mathrm{~K} 20$ & 2 & 14,14 & 22 \\
\hline Faaliyetlerin sınırlı alanda yapılması & $\mathrm{K} 14, \mathrm{~K} 21$ & 2 & 14,14 & 22 \\
\hline Faaliyetlerin tekelde olması & $\mathrm{K} 1, \mathrm{~K} 12$ & 2 & 14,14 & 22 \\
\hline Çevre kirliliği yaratması & $\mathrm{K} 13$ & 1 & 7,7 & 22 \\
\hline
\end{tabular}

Tablo 10 'da görüldüğü gibi katılımcıların belirttiği bölgede yapılan turistik faaliyetlerin en dikkat çeken eksikliklerinin \% 54,54 oranla, "fiyat pahalılığı", \% 31,81 ile "tanıtım ve reklamın yetersiz olması" ve \% 18,18 ile "faaliyetlerin yapılması aşamasında doğal alanların korunmaması" olduğu görülmüştür.

Tablo 11. Katılımcılar Açısından Turizm Faaliyetlerinin Çevreye Zarar Verme Durumu

\begin{tabular}{|c|l|c|c|l|}
\hline $\begin{array}{l}\text { Zarar Verme } \\
\text { Durumu }\end{array}$ & Kat1lımc1lar & $\mathbf{f}$ & Toplam \\
\hline Evet & $\begin{array}{l}\text { K1, K2, K3, K4, K6, K8, K9, K11, } \\
\text { K13, K15, K16, K17, K18,K19, } \\
\text { K20,K21,K22 }\end{array}$ & 18 & 81,81 & 22 \\
\hline Hayır & K5, K7, K10,K12 & 4 & 18,18 & 22 \\
\hline
\end{tabular}

Tablo 11'deki çalışma bulgularında katılımcıların \% 81,81'inin bölgede yapılan turizm faaliyetlerinin çevreye zarar verdiğini düşündüğü, \% 18,18'inin çevreye zarar vermediğini düşündüğü görülmüştür.

Tablo 12 'de görüldüğü gibi bölgede yapılan turizm faaliyetlerinin çevreye verdiğini belirten 18 katılımcının \% 44,44'ünün "'vadi ve yollarının bozulması", \%38,88'inin "balon gazlarının doğal alanlara zarar vermesi" ve \%27,77'sinin "farklı inşaalar yüzünden doğallığın kaybolması", \% 22,22 'sinin "tarım alanlarına zarar verilmesi", \%16,66' sının "fotoğraf çekimlerinden oluşturduğu duvar resimleri, ikonlar ve frekslerin yıpranması, "çevre kirliliği", "'araç trafik sorunu" ve "tarihi ve doğal alanlara yazı yazılması/resim çizilmesi", \%11,11'inin "taşıma kapasitesinin aşılması" ve \% 5,55'inin "kötü koku oluşturması" verilen zararlar arasında belirtilmiştir. 
Tablo 12. Katılımcılar Açısından Bölgede Yapılan Turizm Faaliyetlerinin Çevreye Verdiği Zararlar

\begin{tabular}{|l|l|c|l|l|}
\hline Zararlar & \multicolumn{1}{|c|}{ Katılımcılar } & f & \multicolumn{1}{c|}{$\%$} & Toplam \\
\hline Vadi ve yollarının bozulması & $\begin{array}{l}\text { K1, K2, K13, K14, K15, K16, K19, } \\
\text { K21 }\end{array}$ & 8 & 44,44 & 18 \\
\hline $\begin{array}{l}\text { Yapılan farklı inşaatlar yüzünden } \\
\text { doğallığın kaybolması }\end{array}$ & $\mathrm{K} 3, \mathrm{~K} 6, \mathrm{~K} 9, \mathrm{~K} 19, \mathrm{~K} 20$ & 5 & 27,77 & 18 \\
\hline $\begin{array}{l}\text { Balon gazlarının doğal alanlara } \\
\text { zarar vermesi }\end{array}$ & $\mathrm{K} 1, \mathrm{~K} 2, \mathrm{~K} 11, \mathrm{~K} 14, \mathrm{~K} 15, \mathrm{~K} 17, \mathrm{~K} 19$, & 7 & 38,88 & 18 \\
\hline $\begin{array}{l}\text { Fotoğraf çekimlerinden } \\
\text { oluşturduğu duvar resimleri, } \\
\text { ikonlar ve frekslerin yıpranması }\end{array}$ & $\mathrm{K} 4, \mathrm{~K} 13, \mathrm{~K} 18$, & 3 & 16,66 & 18 \\
\hline Tarım alanlarına zarar verilmesi & $\mathrm{K} 1, \mathrm{~K} 11, \mathrm{~K} 14, \mathrm{~K} 20$ & 4 & 22,22 & 18 \\
\hline $\begin{array}{l}\text { Çevre kirliliği } \\
\text { Araç trafiği sorunu }\end{array}$ & $\mathrm{K} 2, \mathrm{~K} 8, \mathrm{~K} 13$, & 3 & 16,66 & 18 \\
\hline $\begin{array}{l}\text { Tarihi ve doğal yerlere yazı } \\
\text { yazılmas1/ resim çizilmesi }\end{array}$ & $\mathrm{K} 11, \mathrm{~K} 16, \mathrm{~K} 21$ & 3 & 16,66 & 18 \\
\hline Kötü koku oluşturması & $\mathrm{K} 13$ & 3 & 16,66 & 18 \\
\hline Taşıma kapasitesinin aşılması, & $\mathrm{K} 17, \mathrm{~K} 22$ & 1 & 5,55 & 18 \\
\hline
\end{tabular}

Tablo 13. Katılımcılar Açısından Bölgeye Gelen Turistlerin Çevreye Karşı Duyarlılık Alg1 Durumu

\begin{tabular}{|c|l|l|l|l|}
\hline $\begin{array}{l}\text { Duyarlı1ık } \\
\text { Durumu }\end{array}$ & Kat1lımc1lar & F & $\%$ & Toplam \\
\hline Evet & $\begin{array}{l}\text { K1, K2, K3, K4, K5, K6, K7, K8, K9, K10, K11, } \\
\text { K12, K13, K14, K15, K16, K17, K18, } \\
\text { K19,K21,K22 }\end{array}$ & 21 & 95,45 & 22 \\
\hline Hayır & K20 & 1 & 4,55 & 22 \\
\hline
\end{tabular}

Tablo 13 'deki çalışma bulgularında katılımcıların \% 95,45'inin bölgeye gelen turistlerin çevreye karşı duyarlı olduğunu belirttiği, \% 4,55'inin ise çevreye karşı duyarlı olmadığını belirttiği görülmüştür.

Tablo 14. Katılımcılar Açısından Bölgeye Gelen Turistlerin Çevreye Karşı Duyarlılıkları

\begin{tabular}{|l|l|c|c|c|}
\hline Zararlar & \multicolumn{1}{|c|}{ Katılımcılar } & f & \multicolumn{1}{c|}{ Toplam } \\
\hline $\begin{array}{l}\text { Kurallara dikkat } \\
\text { etmeleri }\end{array}$ & $\mathrm{K} 1, \mathrm{~K} 4, \mathrm{~K} 5, \mathrm{~K} 16, \mathrm{~K} 19$ & 5 & 23,80 & 21 \\
\hline $\begin{array}{l}\text { Çevre temizliğine } \\
\text { dikkat etmeleri }\end{array}$ & $\mathrm{K} 2, \mathrm{~K} 6, \mathrm{~K} 7, \mathrm{~K} 10, \mathrm{~K} 13, \mathrm{~K} 15, \mathrm{~K} 18, \mathrm{~K} 21, \mathrm{~K} 22$ & 9 & 42,85 & 21 \\
\hline $\begin{array}{l}\text { Tarihi ve doğal yapılara } \\
\text { özenli yaklaşmaları }\end{array}$ & $\begin{array}{l}\mathrm{K} 2, \mathrm{~K} 3, \mathrm{~K} 5, \mathrm{~K} 6, \mathrm{~K} 7, \mathrm{~K} 8, \mathrm{~K} 9, \mathrm{~K} 11, \mathrm{~K} 12, \mathrm{~K} 14, \\
\mathrm{~K} 17, \mathrm{~K} 21\end{array}$ & 12 & 57,14 & 21 \\
\hline
\end{tabular}


Tablo 14 'e göre turistlerin çevreye karşı duyarlı olduğunu belirten katılımcıların \% 57,14'ünün "tarihi ve doğal yapılara özenli yaklaşmaları", \% 42,85'inin"çevre temizliğine dikkat etmeleri", \% 23,80'inin "kurallara dikkat etmeleri" duyarlılık olarak belirtilmiştir.

Tablo 15. Katılımcıların Turizm Kaynaklarının Ve Çevrenin Korunması Hakkında Devlet Ve Yerel Yönetimlerin Önlem Alma Durumu

\begin{tabular}{|c|l|l|l|l|}
\hline $\begin{array}{l}\text { Önlem Alma } \\
\text { Durumu }\end{array}$ & Kat1lımc1lar & $\mathbf{f}$ & $\mathbf{\%}$ & $\begin{array}{l}\text { Topla } \\
\mathbf{m}\end{array}$ \\
\hline Evet & $\mathrm{K} 1, \mathrm{~K} 2, \mathrm{~K} 4, \mathrm{~K} 5, \mathrm{~K} 6, \mathrm{~K} 7, \mathrm{~K} 8, \mathrm{~K} 13$ & 8 & 36,36 & 22 \\
\hline Hayır & $\begin{array}{l}\mathrm{K} 3, \mathrm{~K} 9, \mathrm{~K} 10, \mathrm{~K} 11, \mathrm{~K} 12, \mathrm{~K} 14, \mathrm{~K} 15, \mathrm{~K} 16, \mathrm{~K} 18, \\
\mathrm{~K} 19, \mathrm{~K} 20, \mathrm{~K} 21, \mathrm{~K} 22\end{array}$ & $\begin{array}{l}63,64 \\
3\end{array}$ & 22 \\
\hline
\end{tabular}

Tablo 15 'deki çalışma bulgularında katılımcıların \% 36,36'sının turizm kaynakları ve çevrenin korunması hakkında devlet ve yerel yönetimlerin yeterli önlem aldığını, \% 63,64' ünün yeterli önlem almadığını belirttiği gözlenmiştir.

Tablo 16. Katılımcılar Açısından Turizm Kaynakları ve Çevrenin Korunması Hakkında Devlet ve Yerel Yönetimlerin Aldığı Önlemler

\begin{tabular}{|l|l|l|l|l|}
\hline Önlemler & \multicolumn{1}{|c|}{ Katılımcılar } & \multicolumn{1}{|c|}{ f } & \multicolumn{1}{|c|}{ \% } & \multicolumn{1}{|c|}{ Toplam } \\
\hline Bölgenin sit alanı yapılması & K1, K8 & 2 & 25 & 8 \\
\hline Yasalar ile çevrenin korunması & K2 & 1 & 17,5 & 8 \\
\hline Kurallar ile faaliyetlere sınırlama getirilmesi & K13 & 1 & 17,5 & 8 \\
\hline $\begin{array}{l}\text { Yöneticilerin sık sık bölgeye gelip denetleme } \\
\text { yapması }\end{array}$ & K2, K5,K13 & 3 & 37,5 & 8 \\
\hline $\begin{array}{l}\text { Halkın bilinçlenmesi için sempozyum } \\
\text { düzenlenmesi }\end{array}$ & K6 & 1 & 17,5 & 8 \\
\hline Çarpık yapılaşma için yasaların çlkarılması & K4 & 1 & 17,5 & 8 \\
\hline Faaliyet alanlarının düzenli denetlenmesi & K4 & 1 & 17,5 & 8 \\
\hline Düzenli temizlik yapılması & K6 & 1 & 17,5 & 8 \\
\hline Sit alanlarına uyarı tabelaları koyulması & K7 & 1 & 17,5 & 8 \\
\hline Çadır ve camping için özel alan belirlenmesi & K4 & 1 & 17,5 & 8 \\
\hline
\end{tabular}

Tablo 16 'ya göre turistlerin çevreye karşı duyarlı olduğunu belirten katılımcıların \% 37,5 'inin " yöneticilerin sık sık bölgeye gelip denetleme yapması", \% 25'inin "bölgenin sit alanı yapılması", \% 17,5'inin "yasalar ile çevrenin korunması", "kurallar ile faaliyetlere sinırlama getirilmesi", "halkın bilinçlenmesi için sempozyum düzenlenmesi", "çarpık yapılaşma için yasaların çıarılması", " faaliyet alanlarının düzenli denetlenmesi", "düzenli temizlik yapılması", "sit alanlarına uyarı tabelaları koyulması" ve "çadır ve camping için özel alan belirlenmesi" alınan önlemler olarak belirtilmiştir. 


\section{SONUÇ ve ÖNERILLER}

Turizm ve rekreasyon faaliyetleri destinasyonlar için büyük önem taşımaktadır. Bu faaliyetlerin olumlu ve olumsuz sonuçları da bölge halkını doğrudan etkilemektedir. Bölge halkının turizm faaliyetlerine karşı algılarını araştırmak, gereksinimlerini karşılamak ve memnuniyet derecelerini yükseltmek hem bölge hem de turistler açısından gereklidir.

Çalışmadan Kapadokya Bölgesi'ni ziyaret eden turistlerin katıldığı aktiviteler arasında çalışmaya katılan yerel halkın hepsinin sıcak hava balonu seyahati yaptığını belirttiği sonucuna varılmıştır. Bunun yanında yerel halk turistlerin en çok günlük bölge turu, ATV turu ve Türk gecesi etkinliğine katıldığını belirtmiştir. Bu sonuca dayanarak bölgeye gelen turistlerin bölgenin rekreatif turistik ürünlerine ilgi gösterdiğini söyleyebiliriz. Diğer bir sonuç olarak katılımcıların \% 54,54'ünün bölgede yapılan turizm faaliyetlerine katılma fırsatı bulabildiği belirlenmiştir. Bölgede yapılan faaliyetler arasında yerel halkın en çok vadi yürüyüşü, sıcak hava balonu seyahati, ATV turu ve çömlek yapımı faaliyetlerine katıldığı yaptığı belirlenmiştir. Bu sonuç itibariyle bölgeye özgü faaliyetlerin bölge halkı tarafından yapıldığı sonucunu çıkmaktadır ve halkın bölgede yapılan faaliyetlere ilgi gösterdiği görülmektedir.

Yerel halk açısından bölgede yapılan turizm ve rekreatif faaliyetlerin eksiklikleri arasında en çok fiyatların pahalı olması, yapılan tanıtım ve reklamın yetersiz olması ve faaliyetlerin yapılması aşamasında doğal alanların korunmaması olduğu belirlenmiştir. Katılımcılar açısından turistlerin bölgeye gelmesinin yerel halk için olumlu sonuçları içinde en çok gelire etkisi, istihdam etkisi ve bölgeyi tanıtıma etkisi olduğu belirlenmiştir. Bu sonuca dayanarak turizm ve rekreatif faaliyetlerin yerel halkın ekonomisi açısından büyük bir önemi bulunmaktadır. Katılımcılar açısından turistlerin bölgeye gelmesinin yerel halk için olumsuz sonuçları içinde ise, en çok "fiyat pahalılığ yaratması", kültürel kimlik, gelenekler ve bölgesel karakterlerde yozlaşma" ve sosyal eşitsizlik oluşturabilmesi" açısından olumsuz sonuçları olduğu göze çarpmaktadır. Bu sonuca dayanarak turistik bölgelerde fiyatların pahalılığı bölgedeki yerel halkın ekonomik anlamda sıkıntıya girmesine ve alım gücünü düşürmesine sebep olmaktadır. Bunun yanında farklı kültür yapısına sahip olan turist ve yerel halkın bir araya gelmesiyle bölgenin gelenek ve göreneklerinin bozulduğu, yerel halkın kültürel özelliklerinde ve yaşam biçimlerinde değişme yaşadığ 1 belirtilebilir. Ayrıca turizm bölgelerinde yerel halkın turistlere gösterilen ilginin yerel halka gösterilmediği hatta yerel halkın turizm ve rekreatif faaliyetlerine katılımının kısıtlandığ söylenebilir (Birinci vd., 2017).

Çalışmanın bir diğer sonucunda ise yerel halkın büyük bir bölümünün turizm ve rekreatif faaliyetlerin çevreye zarar verdiğini belirtmiştir. Yerel halk açısından bölgede yapılan turizm faaliyetlerinin çevreye verdiği zararlar arasında en çok "vadi ve yollarının bozulması', "balondan çıan gazların doğal alanlara zarar vermesi, 'farklı inşaatlar yapılmasından kaynaklı doğallığın kaybolması" şeklinde olduğu belirlenmiştir. Bu sonuç doğrultusunda turizm faaliyetlerinin yerel halkın kullandığı yollara zarar verdiği, bölge halkının turistlerin destinasyondaki doğal alanların doğallığını kaybetmesinden dolayı rahatsız olduğu söylenebilir.

Çalışma sonucuna göre katılımcıların hiçbirinin bölgede turizm faaliyetlerinin yapılmasından rahatsız olmadığı belirlenmiştir. Bu sonuca dayanarak halkın bölgede turizm faaliyetlerinin yapılmasından memnuniyet duyduğunu söyleyebiliriz. Çalışmanın bir diğer sonucunun yerel halkın çoğunluğunun bölgeye gelen turistlerin çevreye karşı duyarlı olduğunu belirttiği, duyarlılık olarak da turistlerin "tarihi ve doğal yapılara özenli yaklaşmaları", "çevre temizliğine dikkat etmeleri" ve "kurallara dikkat etmeleri" olduğu belirtilmiştir. Bundan dolayı turistlerin bölgenin doğal ve tarihi yapısına karşı duyarlı davranışlar sergilediği söylenebilir. Çalışmanın 
sonucu olarak yerel halkın büyük bir bölümünün turizm kaynakları ve çevrenin korunması hakkında devlet ve yerel yönetimlerin önlem almadığını belirttiği görülmüştür. Alınan önlemler arasında en çok "yöneticilerin sık sık bölgeye gelip denetleme yapması", "bölgenin sit alanı yapılması" olduğu belirlenmiştir. Fakat bu önlemlerin yerel halk açısından yeterli bulunmadığı sonucu çıkmaktadır.

Turizm ve rekreatif faaliyetlerin yerel halk açısından olumlu etkilerinin olması yanında olumsuz etkilerinin de olduğu görülmüştür. Araştırma kapsamında yerel halk ile yapılan mülakat sonucunda genel olarak Kapadokya Bölgesi'nde yaşayan yerel halkın genel olarak turizm ve rekreatif faaliyetler hakkında algılarının olumlu olduğu belirlenmiştir. Turizm bölgelerinde yapılan rekreatif faaliyetler için bölge halkının algısı hakkında yapılan bu çalışmanın hem literatüre katkı sağlayacağı düşünülmekte hem de faaliyetlerin bölge için önemine dikkat çekeceği düşünülmektedir. Yerel halkın katılımı ve desteği olmadan turizm ve rekreasyon planlamasının başarısız olabileceği düşüncesiyle, yerel yönetimler tarafından bölge halkı ve turistlerin beraber katılabileceği turizm ve rekreatif faaliyetlerinin planlanması ve projeler hazırlanmasının paydaş olarak yerel halkın da faaliyetlere karşı bilgili ve bilinçlenmesine faydası olacağı düşünülmektedir. Bu çalışma Nevşehir ili içerisinde ikamet eden kişilere uygulanmış olup, çalışma sonrası ortaya çıkan sonuçların sonraki çalışmalarla sınanması ya da benzer bir çalışmanın farklı bir turizm bölgesinde yapılması uygun olabilecektir.

\section{KAYNAKLAR}

Akova, O. (2006). Yerel Halkın Etkilerini Algılamalarına ve Tutumlarına Yönelik Bir Araştırma. Akademik Incelemeler Dergisi (AID), 1(2): 77-109.

Alaeddinoğlu, F. (2007). Van Halkının Turisti ve Turizmi Algılama Şekli. Coğrafi Bilimler Dergisi, $5(1): 1-16$.

Alaeddinoğlu, F. (2008). Sivas Kentinde Halkın Turiste ve Turizme Bakışı. Uluslararası İnsan Bilimleri Dergisi, 5(2): 1-23.

Avcıkurt, C. (2015). Turizmin Sosyolojisi Genel ve Yapısal Yaklaşım, Ankara: Detay Yayıncılık.

Ayaz, N., Artuğer, S. ve Türkmen, F. (2009). Tarihi Zela (Zile) İlçesindeki Yerel Halkın Turizme Bakış Açlarını Belirlemeye Yönelik Bir Alan Araştırması, Ticaret ve Turizm Eğitim Fakültesi Dergisi, 2: 103-124.

Bayat, G. (2010). Turizmin Yerel Halk Tarafından Algılanması: Iğdır Halkı Üzerine Bir Araştırma, Yayınlanmış Yüksek Lisans Tezi, Kafkas Üniversitesi Sosyal Bilimler Enstitüsü, Kars.

Bestard, A. B., and Nadal, J. R. (2007). Modelling Environmental Attitudes Toward Tourism. Tourism Management, 28(3): 688-695.

Biçici, F. (2014). Datça Yerel Halkının Sürdürülebilir Turizm Gelişimine ve Turizm İşletmelerine Yönelik Tutumları. Seyahat ve Otel İşletmeciliği Dergisi, 10(1): 19-35.

Birinci, M. C., Çamlıca, K., ve Katlav, E. Ö. (2017). Üniversite Öğrencilerinin Rekreatif Amaçlı Spor Aktivitelerine Katılmalarını Engelleyen Kısıtlayıcı Faktörler Üzerine Bir Araştırma. TURAN: Stratejik Araştırmalar Merkezi, 9(36): 777-780.

Birinci, M. C. ve Güçer E. (2019). Boş Zaman Motivasyonu ve Davranışsal Niyet İlişkisinde Boş Zaman Tatminin Aracılık Etkisi. Journal of Tourism and Gastronomy Studies, 8(1): 1626-1639. 
Çalışkan, U. ve Tütüncü, Ö. (2008). Turizmin Yerel Halk Üzerindeki Etkileri ve Kuşadası İlçesi Uygulaması. IV. Lisansüstü Turizm Öğrencileri Araştırma Kongresi: 127-148.

Çelikkanat, N. (2015). Yerel Halkın Turizme Bakış Açısı: Bodrum İlçesi Örneği, Yayınlanmış Yüksek Lisans Tezi, Gazi Üniversitesi Sosyal Bilimler Enstitüsü, Ankara.

Çetin, T. (2009). Beypazarı'nda Turist-Yerli Halk Etkileşimin ve Turizmin Sosyal, Kültürel ve Ekonomik Etkileri, Türk Dünyası İncelemeleri Dergisi, 9(1): 15-32.

Çımat, A. ve Bahar, O. (2003). Turizm Sektörünün Türkiye Ekonomisi İçindeki Yeri ve Önemi Üzerine Bir Değerlendirme. Akdeniz İ.I.B.F. Dergisi, 6: 1-18.

Dal N., ve Baysan S. (2007). Kuşadası'nda Kıyı Kullanımı ve Turizmin Mekânsal Etkileri Konusunda Yerel Halkın Tutumları. Ege Coğrafya Dergisi, 16: 69-85.

Diedrich, A. and García-Buades, E. (2009). Local Perceptions of Tourism as Indicators of Destination Decline. Tourism Management, 30(4): 512-521.

Doğan, H., ve Üngüren, E. (2012). Yerel Halkın Isparta Turizmine Yönelik Görüşleri Üzerine Bir Araştırma. Süleyman Demirel Üniversitesi İktisadi ve İdari Bilimler Fakültesi Dergisi, 17(1): 103-122.

Eshliki, S. A., and Kaboudi, M. (2012). Community Perception of Tourism Impacts and Their Participation in Tourism Planning: A Case Study of Ramsar, Iran. Procedia-Social and Behavioral Sciences, 36: 333-341.

Eren, R. ve Aypek, N. (2012). Kırsal Turizm Bölgesinde Yerel Halkın Turizmin Gelişimine Karş1 Tutumları: Cumalıkızık Köyü Örneği. Uluslararası Sosyal ve Ekonomik Bilimler Dergisi, 2(2): 43-47.

Gabriel B., J., Osti, L., and Faccioli, M. (2011). Residents Perception and Attitudes Towards Tourism Impacts. Benchmarking: An International Journal, 18(3): 359-385.

Getz G. (2008). Event Tourism: Definition, Evolution, And Research, Tourism Management, 29 (3); $403-428$.

Gülüm, K. ve Boz, M. (2014). Çanakkale'de Turizmin Ekonomik, Sosyo-Kültürel ve Eğitimsel Etkileri Üzerine Yerel Halkın Görüşleri, Route Educational And Social Science Journal, 1(2): 1-10.

Göktaş, L. S. (2016). Turizmin Kültürel Ve Ahlaki Etkisi: Şanlıurfa İlinde Uygulamalı Bir Araştırma. Selçuk Üniversitesi Sosyal ve Teknik Araştırmalar Dergisi, 12: 104-117.

Gümüş, N. ve Özüpekçe, S. (2009). Foça' da Turizmin Ekonomik, Sosyal, Kültürel ve Çevresel Etkilerine Yönelik Yerel Halkın Görüşleri. Uluslararası İnsan Bilimleri Dergisi, 6(2): 398-417.

Hançer, Ş. ve Mancı, A. R. (2017). Yerel halkın turizme bakış açısının belirlenmesi üzerine bir araştırma: Diyarbakır örneği. Journal of Tourism and Gastronomy Studies, 5(4), 70-91.

İçöz, O. ve Kozak, N. (2002). Turizm Ekonomisi. Ankara: Turhan Kitabevi.

Inskeep, E. (1991). Tourism Planning: An Integrated and Sustainable Development Approach. New York: John Wiley \& Sons.

Karagöz D. (2006). Etkinlik Turizmi ve Etkinlik Turizmi Bağlamında Yabancı Ziyaretçi Harcamalarının Ekonomiye Etkisi: Formula 12005 Türkiye Grand Prix Örneği, Yayımlanmamış Yüksek Lisans Tezi, Anadolu Üniversitesi, Turizm İşletmeciliği Anabilim Dalı, Eskişehir.

Karaküçük, S. ve Akgül, B.M. (2016). Ekorekreasyon Rekreasyon ve Çevre, Ankara: Gazi Kitapevi. 
Kervankıran, İ. (2014). Beypazarı/Ankara Örneğinde Turizmin Ekonomik, Toplumsal ve Çevresel Etkilerine Yerel Halkın Yaklaşımı. SDÜ Fen Edebiyat Fakültesi Sosyal Bilimler Dergisi, 31, 133-153.

Keskin, E. ve Çontu, M. (2011). Mustafapaşa (Sinasos) Kasabasında Yaşayan Halkın Turizme Bakış Açısını Belirlemeye Yönelik Bir Alan Araştırması. Aksaray Üniversitesi İ̈BF Dergisi, 3(2): 3755.

Ko, D.W. and Stewart, W. P. (2002). A Structural Equation Model of Residents Attitudes for Tourism Development. Tourism Management, 23: 521-530.

Latkova, P. and Vogt, C. A. (2012). Residents Attitudes Toward Existing and Future Tourism Development in Rural Communities, Journal of Travel Research, 51(1): 50-67.

Mesci, M. ve Dönmez, G. (2016). Turizmin Bölgesel Kalkınma ve Yerel Halk Üzerindeki Etkisi: Mudurnu Örneği. AİBÜ SBE Dergisi, 16(2), 21-50.

Nunkoo, R., Smith, S. L. J. and Ramkissoon, H. (2013). Residents' Attitudes to Tourism: A Longitudinal Study of 140 Articles From 1984 to 2010. Journal of Sustainable Tourism, 21(1): 5-25.

Oğuz, D. (1991). Sinop Sahil Şeridinin Turizm-Rekreasyon Olanaklarının Saptanması Turistik ve Rekreatif Gelişmelerin Çevre İle Etkileşiminin İrdelenmesi. Yüksek Lisans Tezi, Ankara Üniversitesi, Ankara.

Oğuzbalaban, G. (2017). Türkiye'de Yerel Halkın Turizme ve Turizmin Etkilerine Yönelik Alg1 ve Tutumlarına İlişkin Yazın Taraması, Uluslararası Sosyal Araştırmalar Dergisi,10(51).

Örücü, Ö.K. (2002). Eğirdir Yöresindeki Mevcut Peyzaj Değerlerinin Turizm Açısından Değerlendirilmesi. Yüksek Lisans Tezi, Süleyman Demirel Üniversitesi, Isparta, Türkiye.

Özdemir, M. A. ve Kervankıran, İ. (2011). Turizm ve Turizmin Etkileri Konusunda Yerel Halkın Yaklaşımlarının Belirlenmesi: Afyonkarahisar Örneği, Marmara Coğrafya Dergisi, 24: 1-25.

Özdemir, G. (2014). Destinasyon Yönetimi ve Pazarlanması, Detay Yayıncllı, Ankara.

Panizzon, D. and Boulton, A. (2000), Biodiversity in Australia: What, Where And For How Long?, Australian Science Teachers Journal, 46(4): 17-26.

Sarl, Y. (2001). Amasra İlçesinin Doğal ve Kültürel Peyzaj Değerlerinin Sürdürülebilir Turizm Bağlamında İrdelenmesi, Yüksek Lisans Tezi, Zonguldak Karaelmas Üniversitesi Fen Bilimleri Enstitüsü, 169.

Şahbaz, R. P. (2015). Turizmin Ekonomik, Sosyal (Toplumsal) ve Fiziksel Çevre Etkileri, Zeynep Aslan (Ed.), Genel Turizm İçinde (S. 229-260). Ankara: Detay Yayıncılık.

Toprak, L. (2015). Mardin' de Halkın Turizm Algısı. Elektronik Sosyal Bilimler Dergisi, 14(54), 201218.

Uslu, A. ve Kiper, T. (2006). Turizmin Kültürel Miras Üzerine Etkileri: Beypazarı Ankara Örneğinde Yerel Halkın Farkındalığı, Tekirdă̆ Ziraat Fakültesi Dergisi, 3(3): 305-314.

Vatan, A. ve Zengin, B. (2015). Söğüt İlçesi'nde Kültürel Miras ve Yerel Halkın Turizme Bakış Açısı, Akademik Sosyal Araştırmalar Dergisi, 10: 634-650.

Yayla, Ö. ve Yaylı, A. (2019). Turistik Destinasyonlarda Rekreasyonel Etkinliklerin Hizmet Kalitesi Ölçümü: Kavramsal Bir İnceleme. Journal of Tourism and Gastronomy Studies, 7 (1), 676687. 
Yılmaz, İ. (2017). İl Türkiye'de Turizmin Çevresel, Ekonomik ve Sosyo-Kültürel Etkileri (İçerik Analizine Dayalı Bibliyometrik Bir Yaklaşım). Ankara: Detay Yayıncılık.

Yoon, Y., Gursoy, D., and Chen, J. S. (2001). Validating A Tourism Development Theory with Structural Equation Modeling. Tourism Management, 22(4), 363-372. 